\title{
Research on energy storage at Risø National Laboratory
}

Jensen, K.; Krenk, Steen; Ottosen, N.S.; Rasmussen, I.; Rathmann, Ole; Reffstrup, J.; Thomsen, K.L.; Vigeholm, B.; Wurtz, J.

Publication date:

1979

Document Version

Publisher's PDF, also known as Version of record

Link back to DTU Orbit

Citation (APA):

Jensen, K., Krenk, S., Ottosen, N. S., Rasmussen, I., Rathmann, O., Reffstrup, J., Thomsen, K. L., Vigeholm, B., \& Wurtz, J. (1979). Research on energy storage at Risø National Laboratory. Risø National Laboratory. Risø-M No. 2191

\section{General rights}

Copyright and moral rights for the publications made accessible in the public portal are retained by the authors and/or other copyright owners and it is a condition of accessing publications that users recognise and abide by the legal requirements associated with these rights.

- Users may download and print one copy of any publication from the public portal for the purpose of private study or research.

- You may not further distribute the material or use it for any profit-making activity or commercial gain

- You may freely distribute the URL identifying the publication in the public portal

If you believe that this document breaches copyright please contact us providing details, and we will remove access to the work immediately and investigate your claim 
Ris $\$-M-2191$

RESEARCH ON ENERGY STORAGE AT

RISØ NATIONAL LABORATORY

K. Jensen, S. Krenk, N.S. Ottosen, I. Rasmussen,

o. Rathmann, J. Reffstrup, K.L. Thomsen,

B. Vigeholm, and $\mathrm{J}$. Würtz

Abstract. This paper was presented at the International Assembly on Energy Storage held from May 27 to June 1, 1979 in Dubrovnik, Yugoslavia.

It contains a review of some of the research projects on energy storage at Ris $\varnothing$ National Laboratory. Some of the already obtained results are presented together with planned activities for the next few years.

Some of the projects are carried out in close cooperation with the Laboratory for Energetics at the Technical University of Denmark and the Geological Survey of Denmark.

INIS Descriptors for Chapter 2: Seasonal heat storage in aquifers: AQUIFERS, DISTRICT HEATING, FINITE ELEMENT METHOD, HEAT STORAGE, MATHEMATICAL MODELS, PILOT PLANTS.

UDC 620.92

September 1979

Risø National Laboratory, DK 4000 Rosk11de, Denmark 
ISBN 87-550-0617-5

ISSN 0418-6435

R1sø repro 1979 
CONTENTS

Page

1. GROUND STORAGE FOR THERMAL ENERGY

by ole Rathmann ......................... 5

1.1. General ........................... 5

1.2. Practical layout ...................... 5

1.3. Analysis of idealized system ............. 6

1.4. Computer simulations .................. 11

1.5. Conclusion ......................... 11

2. SEASONAL HEAT STORAGE IN AQUIFERS

by Jan Reffstrup and Jorgen Wütz ............ 14

2.1. General ............................. 14

2.2. Pilot plant ........................ 14

2.3. Mathematical models ................... 16

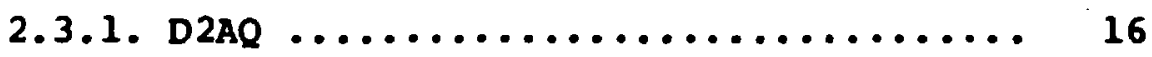

2.3.2. PORFLOW ........................ 18

2.4. References .......................... 18

2.5. Nomenclature ....................... 23

3. NATURAI GAS STORAGE IN SALT CAVERNS

by Steen Krenk, Niels Saabye Ottosen, Knud Jensen

and Ingv. Rasmussen ........................ 24

3.1. Introduction ........................ 24

3.2. Scope of work ........................ 24

3.3. Field investigation and associated laboratory tests ............................... 24

3.4. Conceptual design study ................. 24

3.5. Rock- mechanical safety ............... 26

3.6. Future activities ...................... 29

3.7. References ........................... 29 
Page

4. ENERGY STORAGE BASED IJPON METAL-HYDROGEN SYSTEMS by Bjørn vigeholm ..................... 29

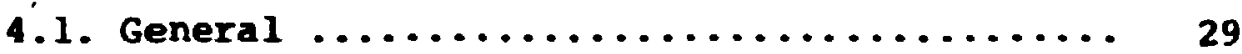

4.2. Results ....................... 30

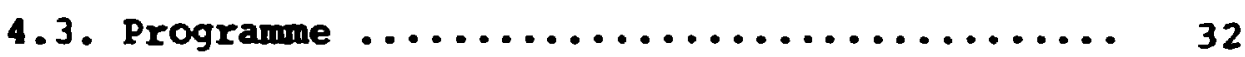

4.4. Impact on energy supply ............. 32

5. STRATIFIED STORAGE FOR SOLAR HEATING SYSTEMS by Knud Ladekarl Thomsen $\ldots \ldots \ldots \ldots \ldots \ldots \ldots \ldots$ 
RESEARCH ON ENERGY STORAGE AT RISø NATIONAL LABORATORY

\begin{abstract}
This paper contains a review of some of the research projects on energy storage at Ris $\varnothing$ National Laboratory, DK-4000 Roskilde, Denmark. The following activities are mentioned:

1. Ground storage for thermal energy,

2. Seasonal heat storage in aquifers,

3. Natural gas storage in salt caverns,

4. Energy storage based upon metal-r.:-drogen systems,

5. Stratified storage for solar heating systems.

1. GROUND STORAGE FOR THERMAL ENERGY
\end{abstract}

Ole Rathmann

\title{
1.1. General
}

The planned widespread use of solar energy has accentuated the need for thermal energy storage devices. As solar energy is expected to meet nearly 1008 of the residential energy demand for space heating and hot water, large seasonal storage is especially needed. However, in order that such a solar energy system be economical, the cost of seasonal storage per unit of storage capacity must be very low. The reason is that seasonal storage has only one charge-recovery-cycle per year.

The Section of Theoretical Heat Transfer and Hydraulics lof the Department of Reactor Technology) has investigated whether or not a finite volume of ground can be used for this type of storage. To maintain costs low the storage is presumed to be insulated only on top.

\subsection{Practical Layout}

The size of the seasonal storage was taken to correspond to a single 


\section{Ole Rathmann}

or a small group of family houses. With this size storage the heat transfer to and from the ground is performed most practically by a closed circuit of heat transfer pipes. In order to avoid excavation, vertical pipes, which can be washed or drilled down, should be chosen. With water as the heat carrying medium the heat transfer pipes are connected to the solar collect: $=$ and the space heating and hot water system as shown in F.ig. 1.1 .

\subsection{Analysis of Idealized System}

In order to get an estimate of the dependence of storage efficiency on storage size an idealized hemispherical ground storage as shown in Fig. 1.2a was analyzed. For simplicity an ideal top insulation was assumed. The heat transfer pipes were represented by simultaneously operating heat sources/drains, homogenously distributed inside the storage volume, so that within this volume the source strength $Q$ depended solely on time.

Next, this ideal system was harmonically analyzed by assuming sinusoidial time dependence of $Q$ and temperature $T$ as shown in $F i g .1 .2 b$, with $Q$ representing the heat loss. This heat conduction problem may be solved analytically when material properties are constant and the result, in the form of temperature amplitude and-phases, is shown in Fig. 1.3. It is seen that the dimensionless storage radius $X$ determines how these quantities vary with the relative distance from the centre. When $X$ is large $(x>>1)$ the amplitude is fairly constant with a phase angle close to $90^{\circ}$ inside the storage volume and falls rapidly to zero outside the storage volume, whereas for $\operatorname{small} x(X \leqslant 1)$ the amplitude falls very slowly to zero outside the storage volume. The stationary profile, $T_{0}(r)-T_{\infty^{\prime}}$ gives the heat loss.

In most cases the maximum temperature "swing" $\Delta T$ determines the total heat capacity of the storage (Fig. 1.4), as, e.g.., one cannot have water at temperatures higher than $100^{\circ} \mathrm{C}$ in a non-pressurized system. This leads to the determination of the storage efficiency. $E$ as shown in Fig. 1.5. The strongest dependence is on $x$, but $a=\frac{i T}{T_{0}-T_{\infty}}$ has also a marked influence as $T_{0}-T_{\infty}$ is responsible for the heat loss.

As an example, for $a=1$ one must have $x>6$ to get a reasonable efficiency $(708)$. For ordinary soil with 20 vol. \& water content

$\left(\mathrm{k}=1.5 \frac{\mathrm{W}}{\mathrm{m}^{\circ} \mathrm{C}}, \mathrm{C}=2 \frac{\mathrm{MJ}}{\mathrm{m}^{\circ} \mathrm{C}}\right.$ ) and $\Delta t=1$ year this lower $1 \mathrm{imit}$ corresponds to $R=11.6 \mathrm{~m}$. Such a storage has a volume of $3300 \mathrm{~m}^{3}$ and a total heat capacity of $264 \mathrm{GJ}$ or $73400 \mathrm{kWh}$ at a temperature swing of $40^{\circ} \mathrm{C}$,
e.g. from $20^{\circ} \mathrm{C}$ to $60^{\circ} \mathrm{C}$.

It should be noted that with a storage radius above this limit the assumption of sinusiodial time dependence of the heat input/output $Q(t)$ is not important, as long as $Q(t)$ is periodic.

This is so because pigher harmonics of $Q(t)$ will introduce higher harmonics in $T(r, t)$ corresponding to higher values of $X$ in $F i g .1 .3$ with only significant influence ingide the storage volume. Thus the total capacity and the efficiency will be almost unchanged. 
Research on Energy Storage at Ris $\$$ National Laboratory
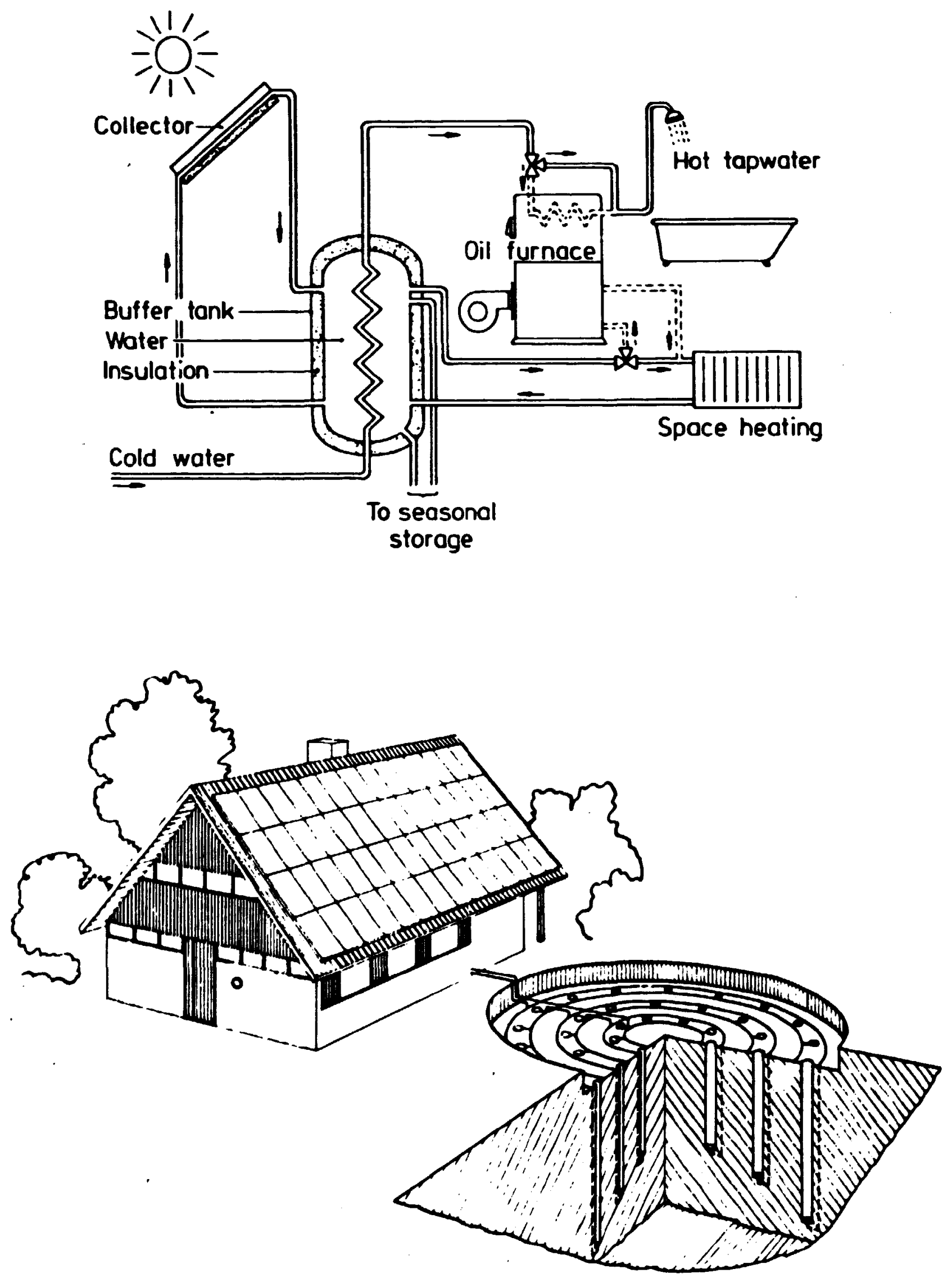

Fig. 1.1. Solar collector, seasonal storage and space heating/hot water system. 
a
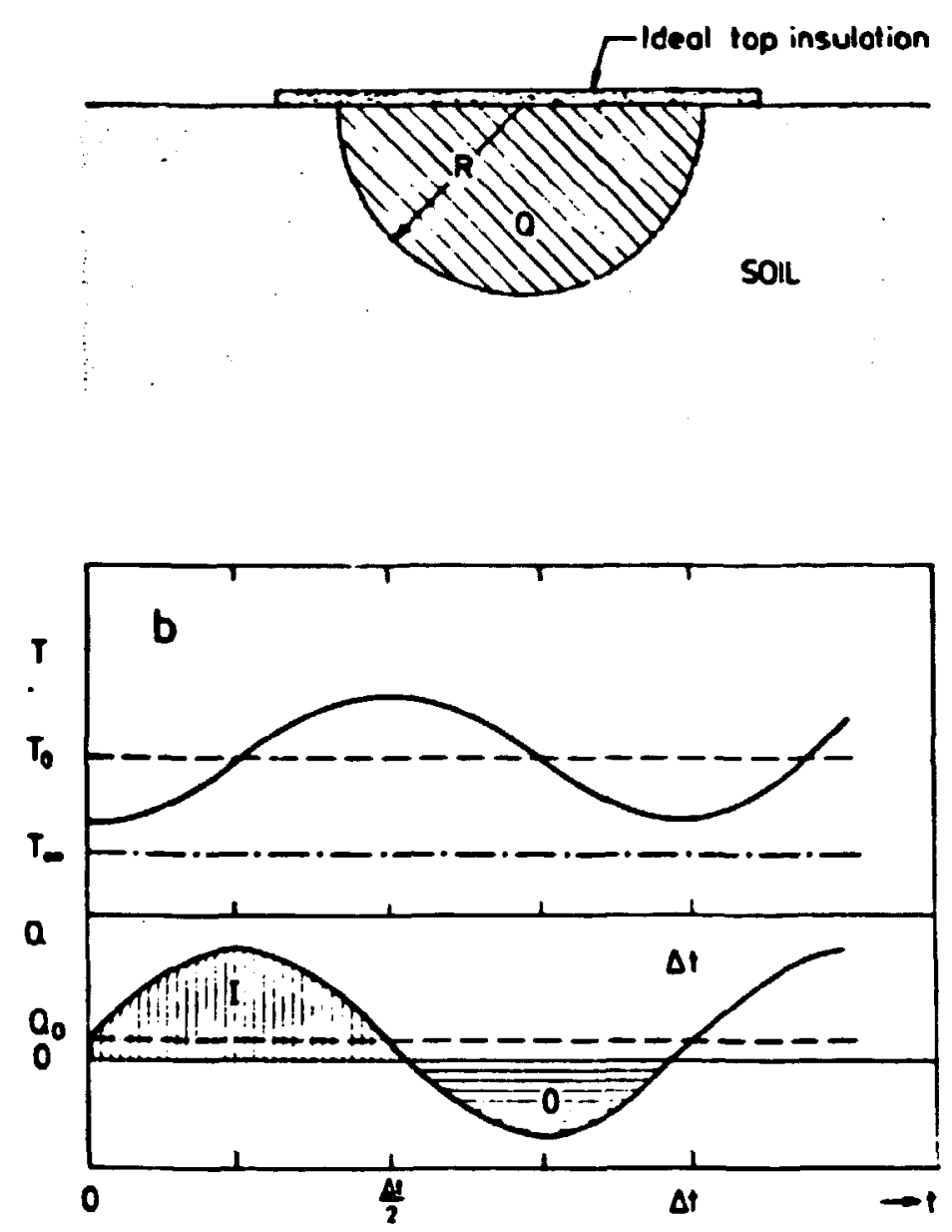

Fig. 1.2. Harmonic Analysis of Ideal Storage.

a. Geometry.

Storage: No top-heat loss.

No ground water.

Hemispherical.

Spherical symmetry.

Heat sources/drains (Q) :

Homogenously distributed.

Operating simultaneously.

b. Variation of temperature $T$ and source strength $Q$ with time $Q(t)=Q_{0}+Q_{\omega} \sin (\omega t)$

$T(r, t)=T_{0}(r, t)+T_{\omega}(r, t) \sin (\omega r-\phi(r))$

$\omega=\frac{2 \pi}{\Delta t}$

The integrated heat input (I) and -output (O) during one cycle are indicated. $T_{\infty}$ is the temperature at infinite distance. 
Research on Energy Storage at Ris $₫$ National Laboratory

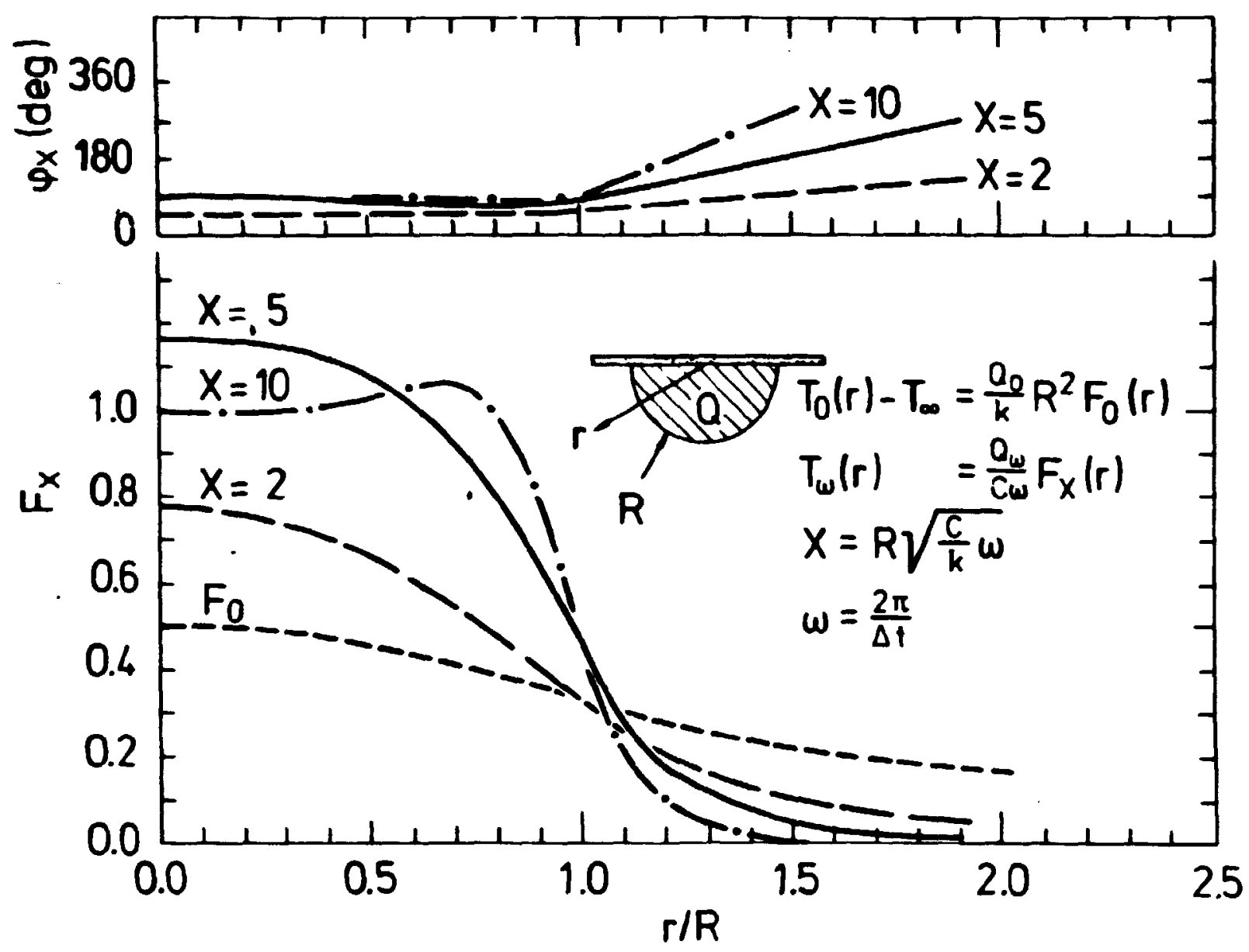

Fig. 1.3. Amplitude and phase of temperature as a function of relative distance from centre.

The dimensionless parameter $x$ is the storage radius relative to the distance travelled by a "temperature wave" in time $C t$.

$c$ is the volumetric heat capacity $\left(\mathrm{J} / \mathrm{m}^{3}{ }^{\circ} \mathrm{C}\right)$ and $k$ is the thermal conductivity $\left(w / m{ }^{\circ} \mathrm{C}\right)$.

The heat loss per cycle is

$L=\frac{4 \pi}{3} R k\left(T_{0}(0)-T_{\infty}\right) \Delta t$. 


\section{Ole Rathmann}

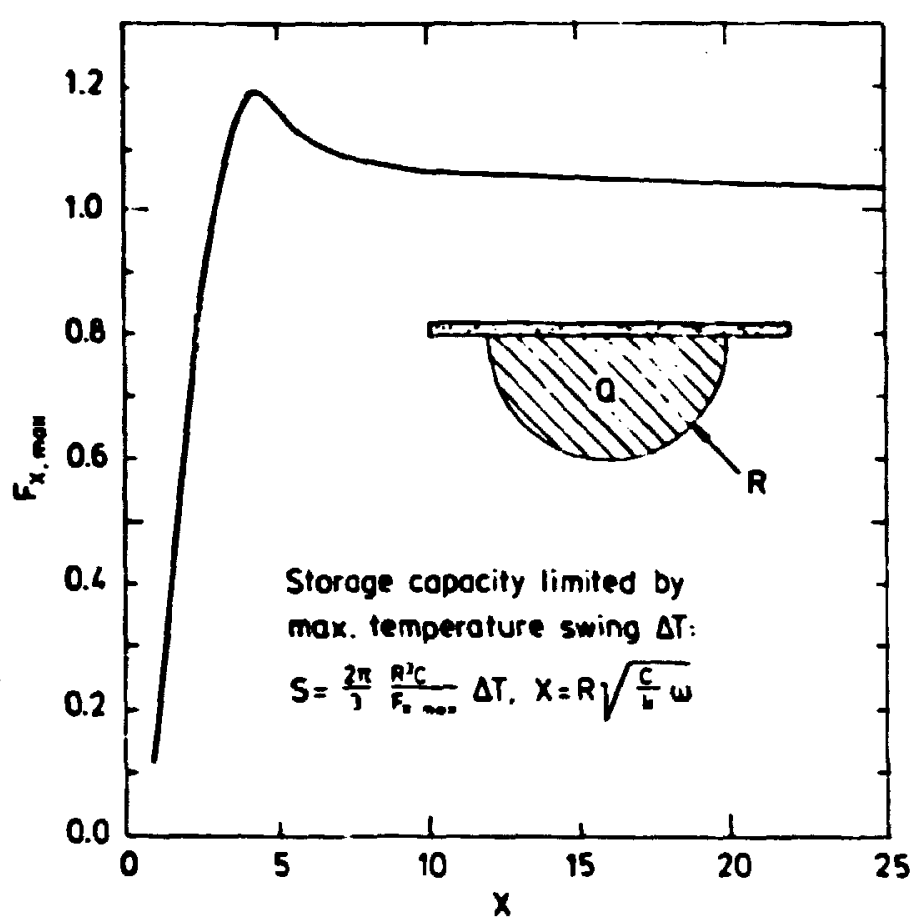

Fig. 1.4. Total storage capacity.

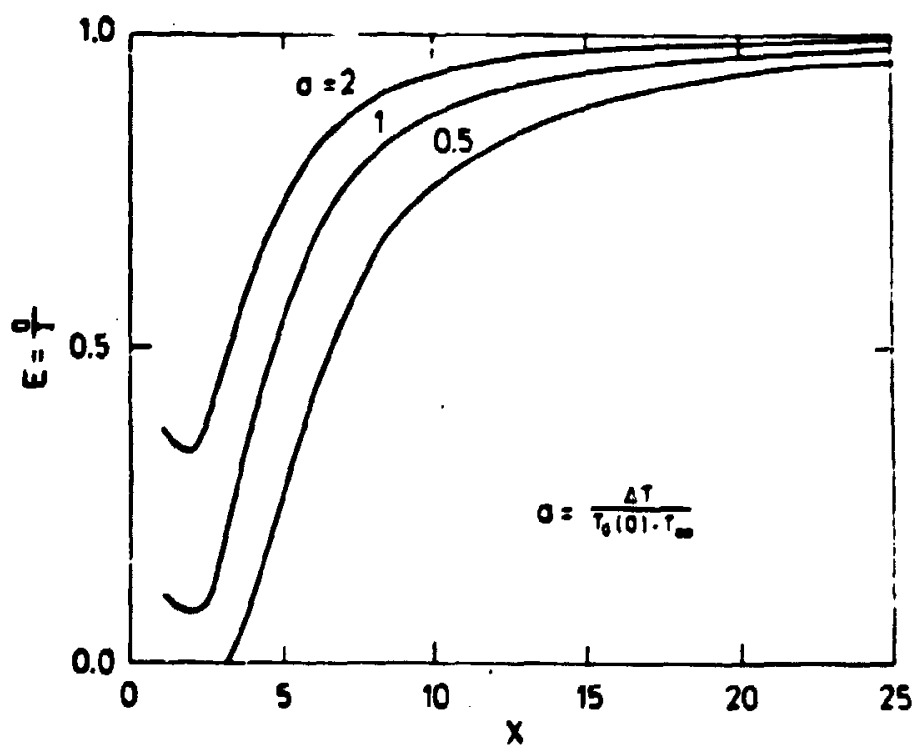

Fig. 1.5. Storage efficiency E.

$E$ = (Integrated heat output)/ (Integrated heat input) per cycle.

$T(0)-T_{0} 18$ the difference between the time aberage centre temperature and the temperature at infinite distance (see Fig. 1.2.). 


\subsection{Computer Simulation}

In order to estimate the effect of removing the ideal assumptions various computer simulations of a ground heat storage were performed, two of which will be presented here.

The new effects taken into account were: (1) top heat loss, (2) presence of stagnant ground water, (3) discrete heat transfer pipes, and (4) non-sinusoidial time dependence of heat input/output.

The storage considered had a radius just at the lower limit found in Section 1.3 and the geometry is shown in Fig. 1.6. The spacing between the heat transfer pipes was chosen from simulations of systems with various spacings.

The storage was assumgd to be connected with 10 family houses equipped with a total of $500 \mathrm{~m}^{2}$ flat solar collectors and with a total heat consumption of. $220 \mathrm{MWh}$. The heat output from the solar collectors was calculated on the basis of the Danish standard year. In the summer (charge) period the water in the heat transfer pipes was limited to $100^{\circ} \mathrm{C}$ and in the winter (recovery) period only water from the storage reservoir with temperature higher than $30^{\circ} \mathrm{C}$ was utilized.

The simulations were performed by means of a finite element heat conduction program assuming rotational symnetry around the vertical centreline. Effective heat transfer coefficients for the heat transfer pipes were used to account for the discreteness of these in the azimuthal direction. The temperature at an infinite distance was set at $7 \mathrm{C}$, independent of time.

The simulation was performed for two cases:

(a) one without and (b) one with ground water (stagnant) at $5.5 \mathrm{~m}$ below ground level. The soil properties are given in Table 1.1.

The resulting heat input/output during one year for case (a) is shown in Fig. 1.7. The simulation efficiency was found as 638 to be compared with the "ideal value" of 748 .

The non-ideal effects (1), (3), and (4) thus reduce the efficiency by about 108 .

When simulating case 0 the presence of even stagnant ground water in the lower half of the storage was found to reduce the efficiency further by 128 down to 518 . Apparently the higher thermal conductivity in the ground water region is not completely counteracted by the increase in the total thermal capacity.

When looking at the performance of the total solar energy system, the simulation of case a showed that during the winter months (November to March) 808 of the consumption was delivered by the solar energy system. or on a yearly basis 888 . For case b the corresponding figures are 728 and 838 .

\subsection{Conclusion}

The simulation results may be somewhat optimistic, as a large fraction 
Ole Rathmann

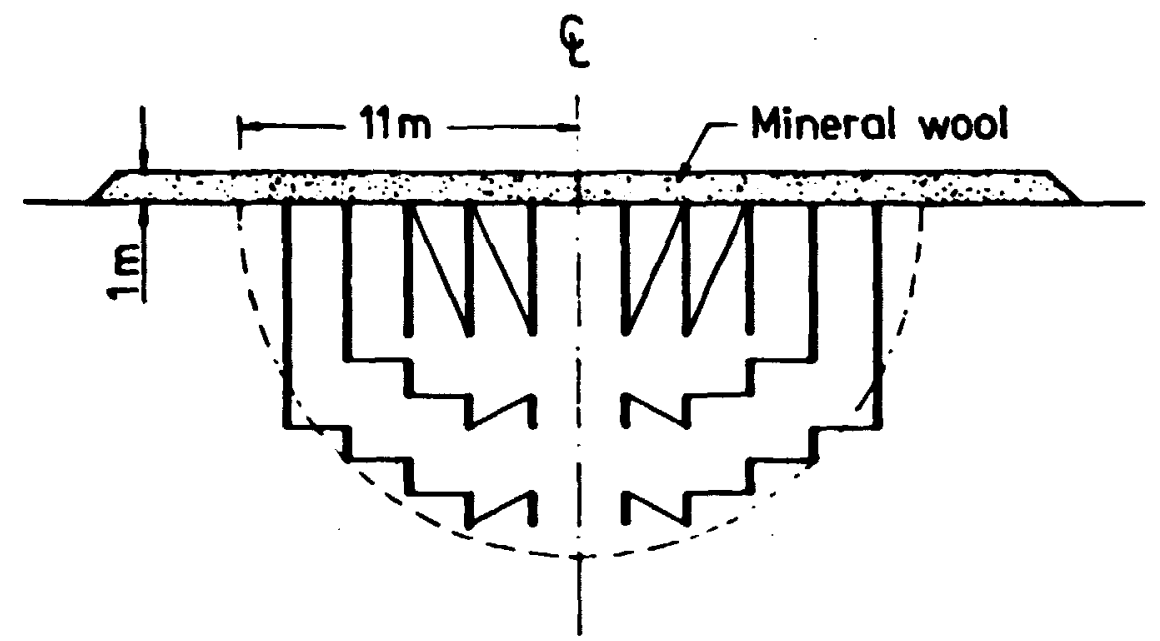

Fig. 1.6. Geometry of simulated ground heat storage. Heat transfer pipes are indicated by bold lines, connection pipes by thin : ines.

The heat transfer pipes have a diameter of $5 \mathrm{~cm}$ and a spacing in each "circle" of $80 \mathrm{~cm}$, giving a total length of $1280 \mathrm{~m}$.

In the charge period the water flow direction is away from the centre, in the recovery period towards the centre.

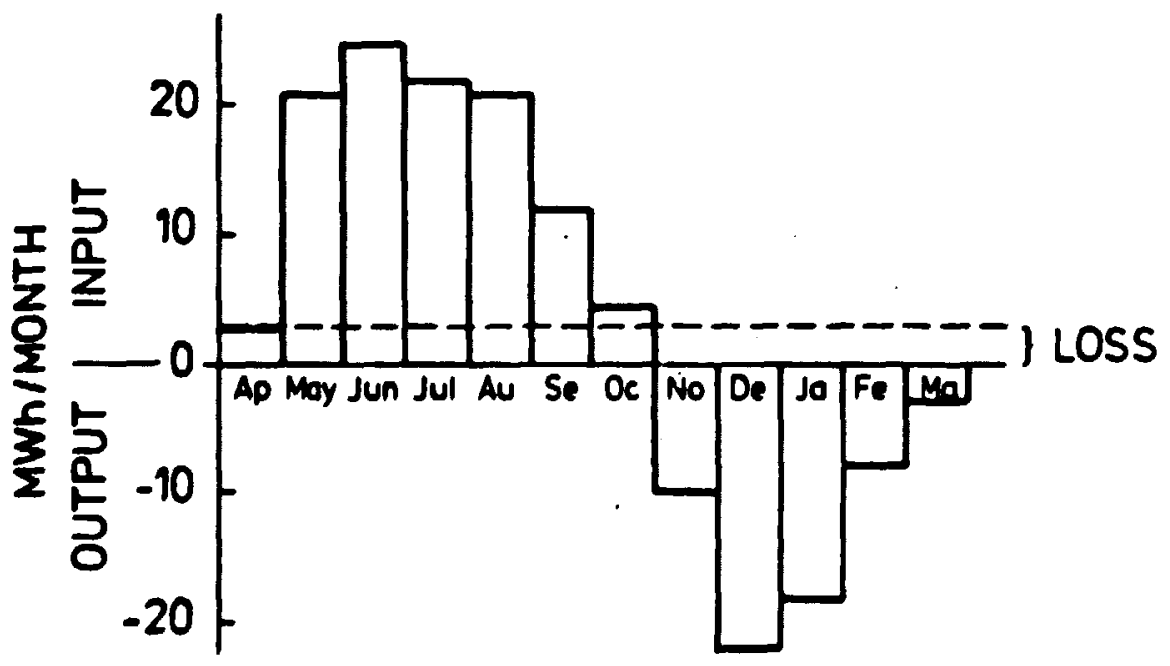

Fig. 1.7. Simulated heat input/output to and from the storage facility for case a. The resulting storage efficiency is $E=638$. 
Research on Energy Storage at Ris $\varnothing$ National Laboratory

Table 1.1. Scil Properties for the Simulations

\section{Case a}

All over.

Clay-sand-10 vol.8 water

$k=0.9 \frac{\mathrm{W}}{\mathrm{m}^{\circ} \mathrm{C}}$

$\mathrm{C}=1.7 \frac{\mathrm{MJ}}{\mathrm{m}^{3} \mathrm{O}_{\mathrm{C}}}$

\section{Case b}

Above groundwater level

(5.5 $\mathrm{m}$ below ground level):

As case a.

Below groundwater level

Sands - 40 vol. 8 water

$$
\begin{aligned}
& k=2.2 \frac{\mathrm{w}}{\mathrm{m}{ }^{{ }^{C} \mathrm{C}}} \\
& \mathrm{c}=2.9 \frac{\mathrm{MJ}}{\mathrm{m}^{3}{ }^{{ }^{\circ} \mathrm{C}}}
\end{aligned}
$$

Simulation storage efficiency:

$E=638$

$E=518$ 
Jan Reffstrup and Jørgen würtz

of the stored energy is recovered as hot water at only $30^{\circ} \mathrm{C}$ to $35^{\circ} \mathrm{C}$; it is therefore difficult to utilize this energy unless very large heating areas - or a heat pump - are used in the space heating plant. On the other hand, the slight horizontal temperature stratification (increasing temperature towards the centre) may be utilized, as the outermost heat transfer pipes may be used solely for preheating hot tap water.

However, the presented results indicate that ground heat storage can work reasonably well provided that it has a sufficiently large size (corresponding to at least 10 family houses) and that the spacing between the heat transfer pipes is sufficiently small $(0.5$ to $1 \mathrm{~m})$.

The great length of heat transfer piping is a serious problem in attempting to reduce costs. A real economic study is outside the scope of this work, however. Neither have the environmental effects of ground heat storage been considered, although they might be serious.

\section{SEASONAL HEAT STORAGE IN AQUIFERS}

Jan Reffstrup $x$ ) and Jørgen würtz

\subsection{General}

Seasonal storage of hot water in natural aquifers (porous layers of gravel or sand) was proposed by Meyer and Todd (1973).

Such a storage method may be used to meet a part of the demand of a district ating system in the winter season by means of excess heat produced ay combined heat and power plants in the summer season.

A rough estimate by Qvale (1976) indicates that 88 of the energy consumption (of a total of 408 ) in the heating sector in Denmark can be saved by using plants with combined generation of heat and electricity rather than by individual oil furnaces and central power stations. Another 8 per cent may be saved by introducing energy storage. Moreover, most of the first 8 per cent will not be economically competitive without the use of seasonal energy storage.

Risø National Laboratory participates in a joint project on aguifer storage together with laboratories at the Technical University of Denmark and the Geological Survey of Denmark. The project includes geological exploration, construction and test run of a pilot plant and development of mathematical models.

\subsection{Pilot Plant}

The pilot plant is shown in conceptual form in Fig. 2.1. The height of the aquifer is approx. $30 \mathrm{~m}$ and the distance from the centre to one of the four outer relief wells is also approx. $30 \mathrm{~m}$. The storage volume is thus approx. $100,000 \mathrm{~m}^{3}$. The test period is planned to be 2 years, so 2 cycles are covered. The periods for pumping up and

x) Laboratory for Energetics, Technical University of Denmark, DK-2800 Lyngby, Denmark. 
Research on Energy Storage at Risø National Laboratory

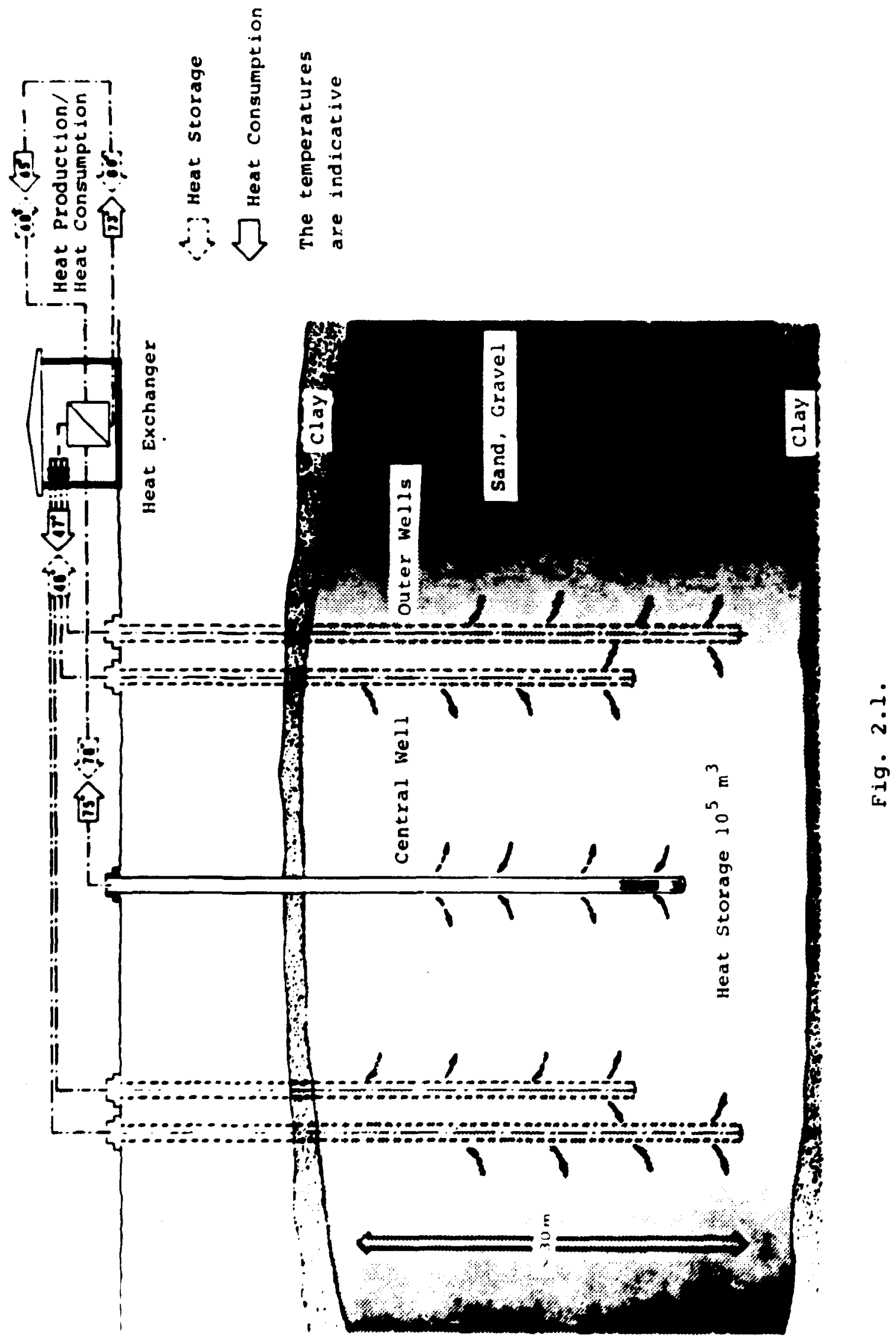




\section{Jan Reffstrup and Jørgen wïrtz}

down are planned to be 4 months each. In the example shown, where the temperature from the combined heat and power plant is $80^{\circ} \mathrm{C}$ and the temperature of the wate: at the relief wells is $46^{\circ} \mathrm{C}$, the efficiency in the second cycle is calculated to be 0.8 . In the first cycle, where the initial temperature in the storage is approx. $8 \mathrm{C}$, the efficiency is approx. 0.36. The storage capacity is about 2 Tcal or approx. $10,000 \mathrm{GJ}$. The volumetric flow rate in the pumping periods is approx. $30 \mathrm{~m}^{3} / \mathrm{h}(8.33 \mathrm{l} / \mathrm{sec})$ and the heat flow rate is about

$1 \mathrm{MW}$.

The test period is planned to start in 1980.

\subsection{Mathematical Models}

Hitherto two 2-dimensional (or axisymmetrical 3-dimensional) models have been developed: A simplified model PORFLOW and a more detailed model D2A.Q. It is planned to develop a (fully) 3-dimensional model on the basis of these two models. Due to the similarity in the heat and mass transfer in aquifers and in geothermal reservoirs, the models are also able to simulate the operations of a geothermal reservoir. In both models the finite element method has been alplied for numerical solution of the governing equations.

\subsubsection{D2AQ}

The detailed model D2AQ has been developed at the Laboratory for Energetics at the Technical University of Denmark.

The three-dimensional axisymmetric numerical simulation model is based on the numerical solution of the coupled heat and fluid flow equations, which are (for nomenclature, see section 2.5.):

\section{Conservation of Mass}

$$
\frac{1}{r} \frac{\partial}{\partial r}\left(r \cdot \rho_{f} u_{r}\right)+\frac{\partial}{\partial z}\left(\rho_{f} u_{z}\right)=-\frac{\partial\left(\rho_{E} \cdot n\right)}{\partial t}
$$

Conservation of Momentum (The Darcy Equations)

$$
\begin{aligned}
& u_{r}=-\frac{k_{r}}{\mu_{f}} \frac{\partial p}{\partial r} \\
& u_{z}=-\frac{k_{z}}{\mu_{f}}\left(\frac{\partial p}{\partial z}+p_{f} \cdot g\right)
\end{aligned}
$$

\section{Conservation of Energy}

$$
\begin{aligned}
& \frac{1}{r} \frac{\partial}{\partial r}\left(r \cdot \lambda_{e} \frac{\partial T}{\partial r}\right)+\frac{\partial}{\partial z}\left(\lambda_{e} \frac{\partial T}{\partial z}\right)- \\
& \rho_{f} C_{v f} u_{r} \frac{\partial T}{\partial r}-\rho_{f} C_{v f} u_{z} \frac{\partial T}{\partial z}= \\
& \left(\rho_{f} C_{v f} n+\rho_{s} C_{v s}(1-n)\right) \frac{\partial T}{\partial t}
\end{aligned}
$$


Eugutions of State

$$
\begin{aligned}
& p_{f}=p_{f}(T) \\
& \mu_{f}=\mu_{f}(T)
\end{aligned}
$$

plus initial and boundary conditions.

Substitution of the Darcy equation yields

$$
\begin{aligned}
\frac{1}{r} \frac{\partial}{\partial r}\left(-r \cdot \rho_{f} \cdot \frac{k_{r}}{u_{f}} \frac{\partial p}{\partial r}\right)+\frac{\partial}{\partial z}\left(-p_{f} \frac{k_{z}}{L_{f}}\left(\frac{\partial p}{\partial z}+\bar{j}_{f} \cdot g\right)\right)= \\
-\frac{\partial\left(\rho_{f} n\right)}{\partial t}
\end{aligned}
$$

Equations (2) to (7) form the mathematical basis for simulation of the coupled heat and fluid flow in aquifers.

\section{Method of Solution}

The numerical solution of the mathematical problem defined by equations (2) to (7) has been obtained by using the finite element method to solve the problem in space and the finite difference method to move the solution ahead in time.

The isoparametric quadrilateral element shown in Fig. 2.2 was used in the finite element solution, whereas the Crank-Nicholson finite difference method has been used for the time integration of the solution.

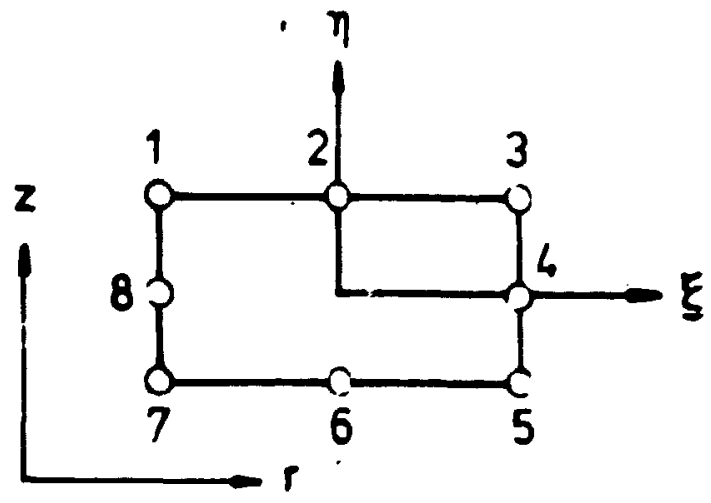

Fig. 2.2. Isoparametric quadrilateral element used in the finite element solution. 
Examples of Solution

In Figs. 2.3-2.5 examples of simuiations with DzAQ are shown. The following input data have been used:

$\begin{array}{ll}\text { Injection rate } & 61 \mathrm{fsec} \\ \text { Injection temperature } & 100^{\circ} \mathrm{C} \\ \text { Initial temperature } & 10^{\circ} \mathrm{C} \\ \text { Aquifer height } & 30 \mathrm{~m} \\ \text { Aquifer radius } & 45 \mathrm{~m} \\ \text { Permeability } & 5 \text { Darcy }=5 \times 10^{-12} \mathrm{~m}^{2}\end{array}$

The temperature distribution is represented by isothermals for 10 , $30,50,70$, and 90 per cent of the difference between the injection and the initial temperature. The flow field is represented by velocity vectors multiplied by the radial position $r$. The variations of the mean temperatures at the central well $(\mathrm{CW})$ and the outer relief wells (REW) are shown together with the variation in the pump head and the injection rate. From the figures it is seen that the thermal front capsizes so that the effective storage volume becomes significantly reduced. However, simulations made with the models show that the buoyancy-driven overshoot of the hot water can be reduced in several ways. An example will be given in the next section.

\subsubsection{PORFLOW}

In PORFLOW, which is developed at Ris National Laboratory, the temperature field is represented in a simplified way by a hot water zone and a cold water zone (CF. Rathmann (1978)). On this basis the water flow is calculated, and the front between the hot zone and the cold zone is traced throughout the storage cycle.

The pressure and flow equations $(1)-(3)$ are solved by means of simple linear triangular elements. The energy equation (4) is reduced to a thermal front equation, which is solved by means of a one-dimensional finite element method. Because of these simplifications, PORFLOW is a faster working computer code than D2AQ. However, details such as the thermal front width cannot be calculated by means of PORFLOW. Typical results are shown on Fig. 2.6. Here is illustrated a method to compensate for the buoyancy-driven overshoot of the hot water.

\subsection{References}

C.F. Meyer and D.K. Todd, Conserving Energy with Heat storage Wells. Environmental Science and Technology 7, 512-516 (1973).

O. Rathmann, PORfLOW: A Computer Finite Element Model for Aquifer Simulation, Risø National Laboratory, Department of Reactor Technology, SOL-7, 58 pp. (1978). Internal report.

B. Qvale, Seasonal Storage of Thermal Energy in Water in the Underground. $8 \mathrm{pp}$. Paper presented at the 1976 IECEC. 
Research on Energy Storage at Ris $\phi$ National Laboratory
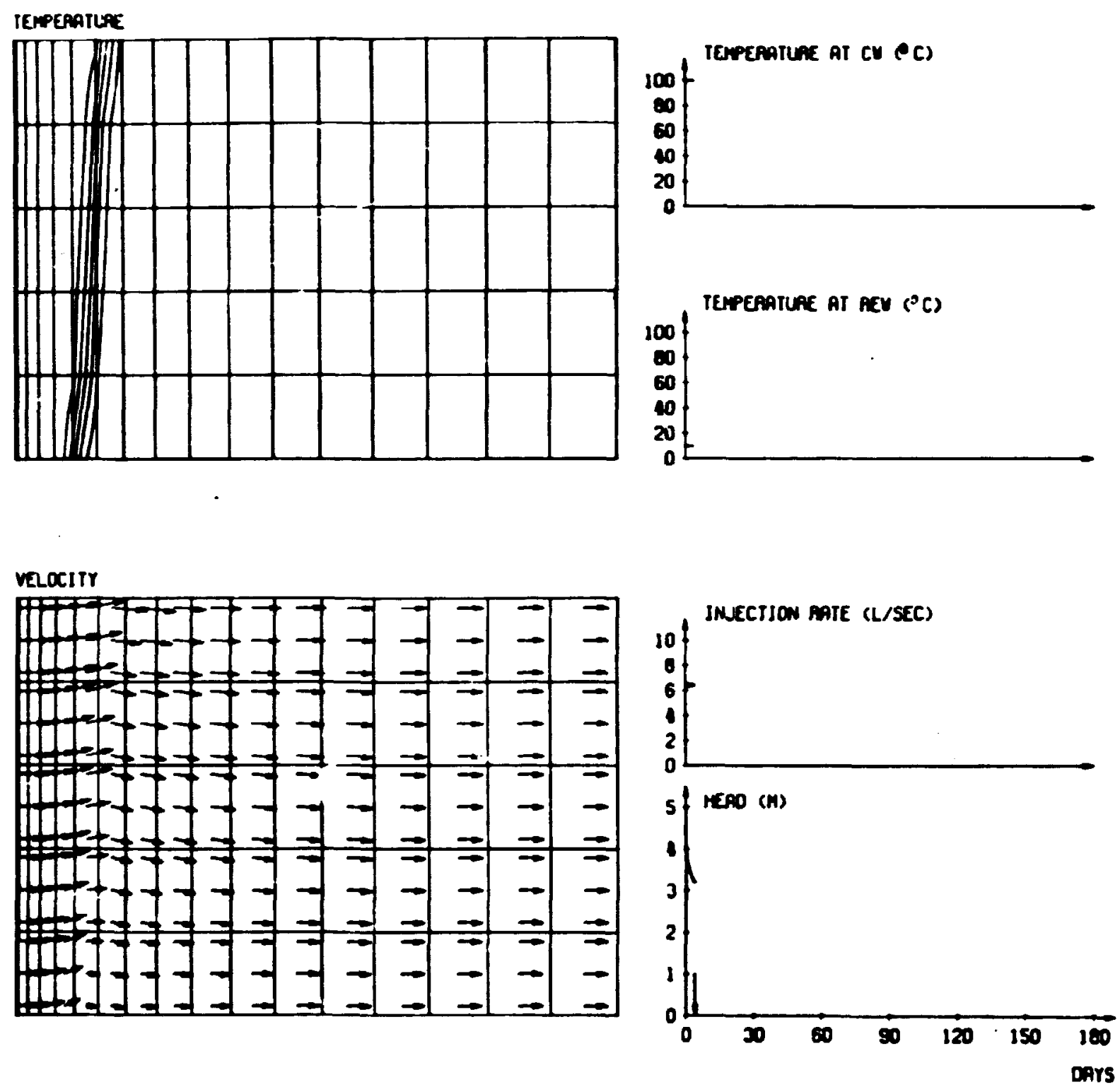

Fig. 2.3. Temperature disiribution and flow field just after start-up. (5 days of operation.) Aquifer height $30 \mathrm{~m}$, radius $45 \mathrm{~m}$, permeability 5 Darcy. 
Jan Reffstrup and Jørgen Würtz

TERPtaAture
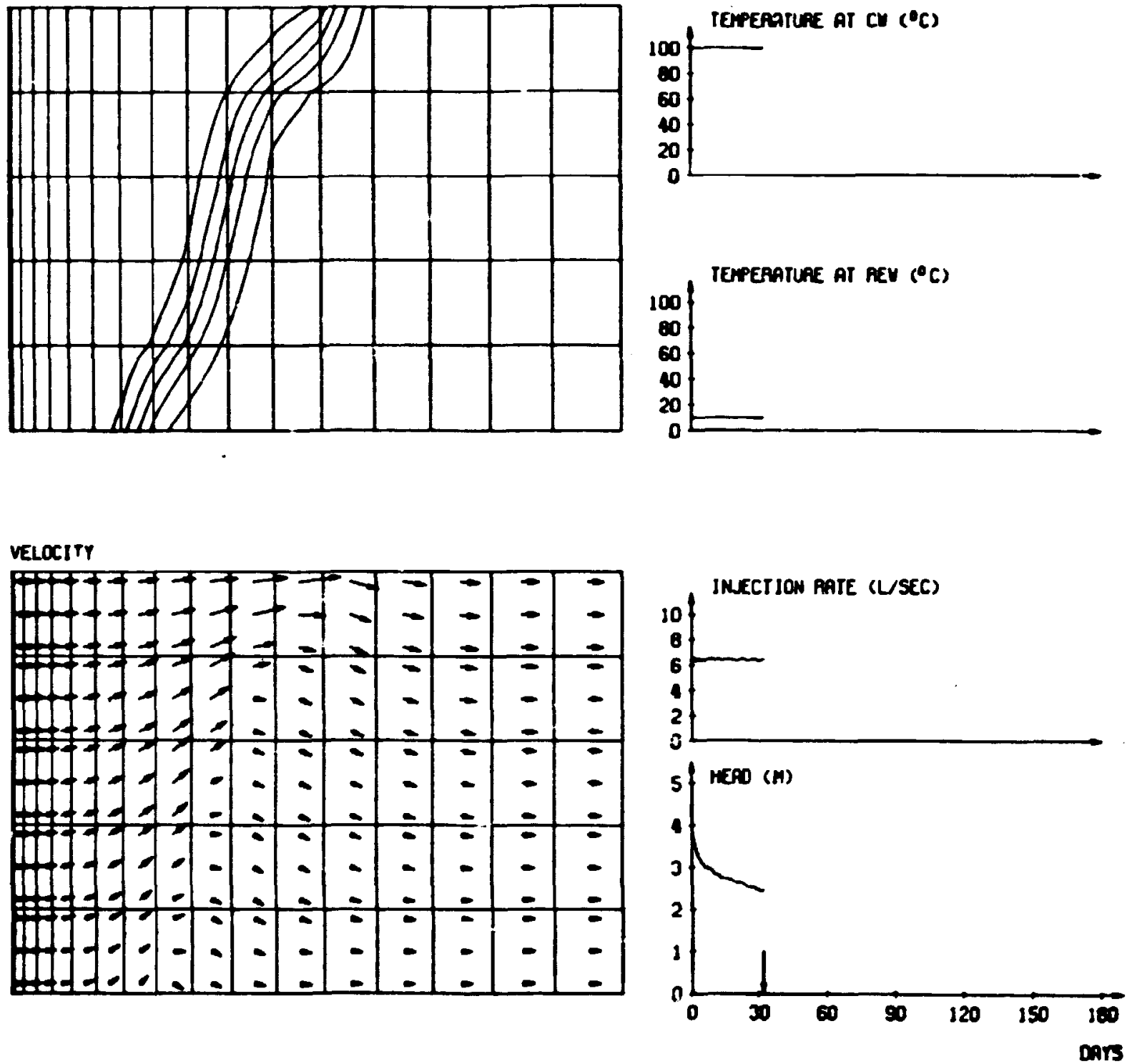

Fig. 2.4. Temperature distribution and flow field after 32 days of operation. Notice the buoyancy-driven overshoot of the hot injected water. The drop in pump head is due to the decrease in viscosity. 

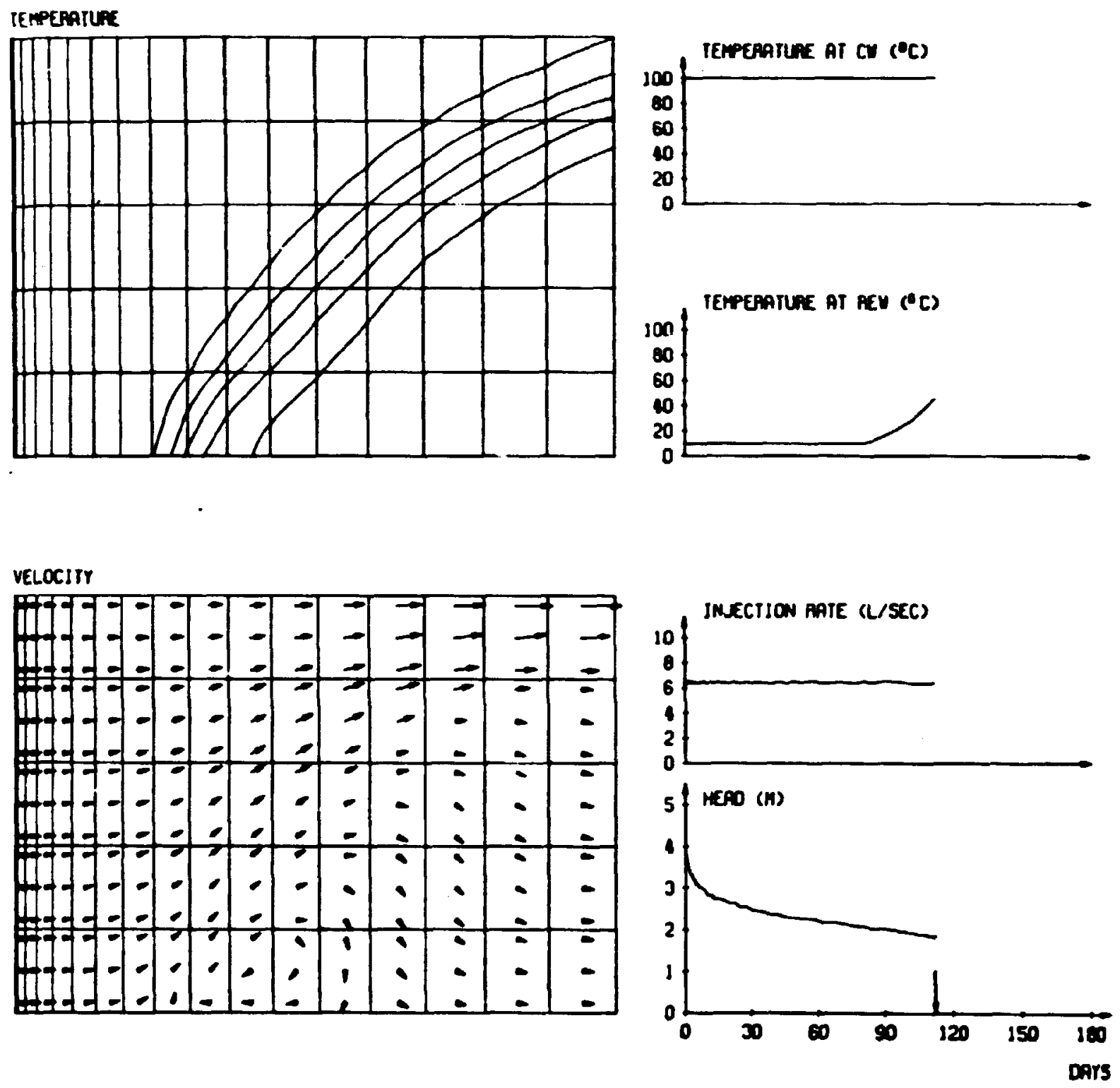

Fig. 2.5. Temperature distribution and flow field at the end of the pump-down period (110 days of operation.) The mean temperature at the outer wells (REW) has now become $40 \mathrm{C}$. It is seen that a significant part of the storage volume cannot be utilized because of the capsize of the thermal front. 
Jan Reffstrup and Jørgen würtz
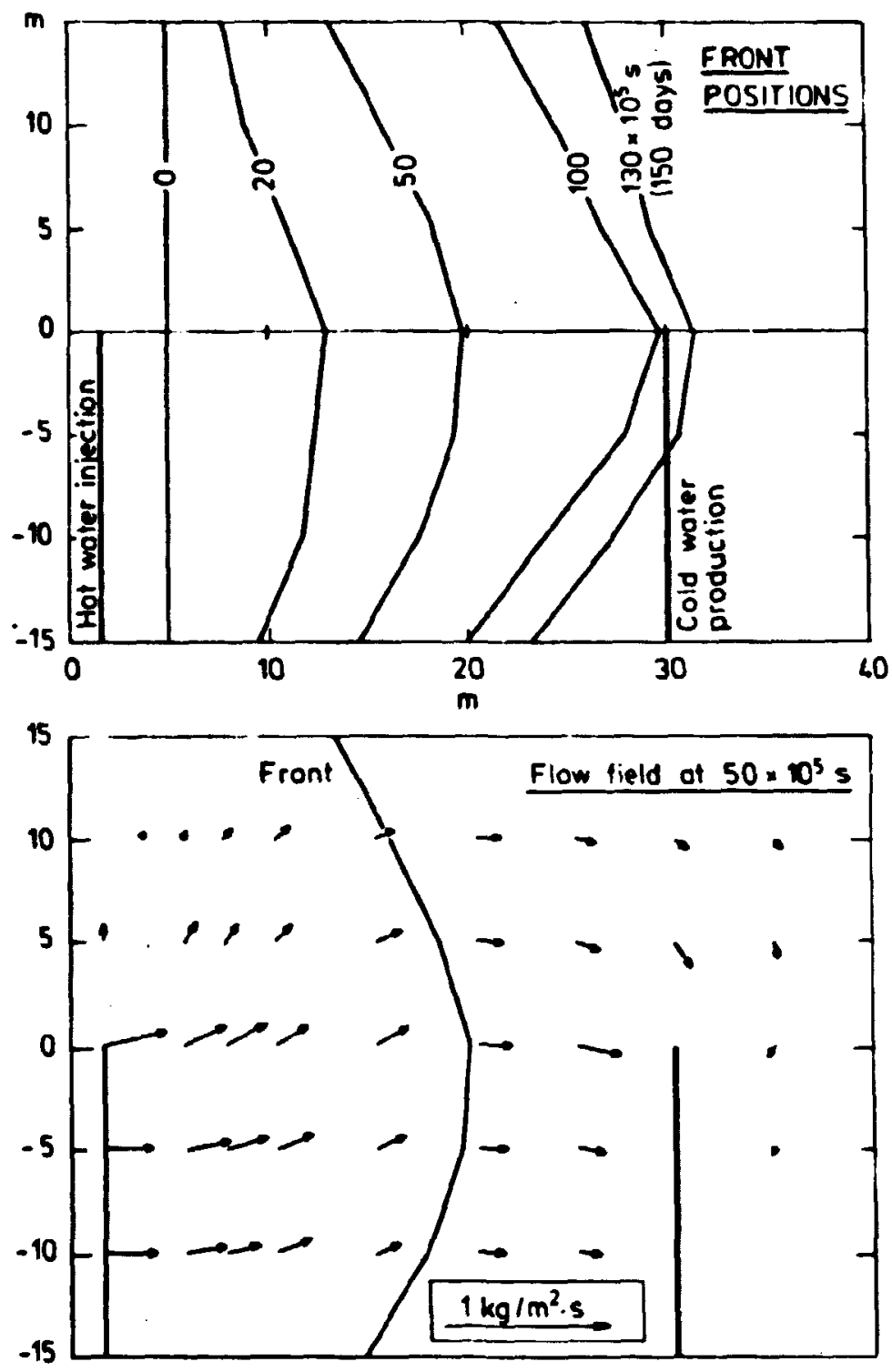

Fig. 2.6. Typical front movement during hot water injection. With a permeability of 2.6 Darcy $=2.6 \times 10^{-12} \mathrm{~m}^{2}$ the driving pressure is $18.1 \mathrm{kPa}$. The hot water is $90^{\circ} \mathrm{C}$ and the cold water is $10^{\circ} \mathrm{C}$.

Uppex half: The front position at different times is shown. The central well and the outer well are only open in the lower half of the aquifer to compensate for the buoyancy-driven overshoot of the hot water.

Lower half: The flow fleld at $50 \times 10^{5} \mathrm{~s}$ is shown. The flow rate at a certain point is represented by a flow vector, starting at that point. 


\section{Research on Energy Storage at Ris $\varnothing$ National Laboratory}

2.5. Nomenclature

$\begin{array}{lll}\mathrm{C}_{\mathrm{v}} & \mathrm{J} / \mathrm{kg}^{\circ} \mathrm{C} & \text { Heat capacity at constant volume } \\ \mathrm{g} & \mathrm{m} / \mathrm{s}^{2} & \text { Gravitational acceleration } \\ \mathrm{k} & \mathrm{m}^{2} & \text { Permeability } \\ \mathrm{n} & - & \text { Porosity } \\ \mathrm{p} & \mathrm{N} / \mathrm{m}^{2} & \text { Pressure } \\ \mathrm{r} & \mathrm{m} & \text { Radial coordinate } \\ \mathrm{t} & \mathrm{s} & \text { Time } \\ \mathrm{T} & { }^{\mathrm{C}} \mathrm{C} & \text { Temperature } \\ \mathrm{u} & \mathrm{m} / \mathrm{s} & \text { Velocity } \\ \mathrm{z} & \mathrm{m} & \text { Axial coordinate } \\ \lambda & \mathrm{W} / \mathrm{m}^{\circ} \mathrm{C} & \begin{array}{l}\text { Effective heat conductivity } \\ \text { of water-saturated soil }\end{array} \\ \mathrm{H} & \mathrm{kg} / \mathrm{ms} & \text { Dynamic viscosity } \\ \mathrm{p} & \mathrm{kg} / \mathrm{m}^{3} & \text { Density }\end{array}$

\section{Subscripts}

$\begin{array}{ll}\mathbf{f} & \text { Fluid (water) } \\ \mathbf{s} & \text { Radial } \\ z & \text { Solid (soil) } \\ & \text { Axial }\end{array}$


Steen Krenk et al.

\section{NATURAL GAS STORAGE IN SALT CAVERNS}

Steen Krenk, Niels Saabye Dttosen, Knud Jensen and Ingv. Rasmussen

\subsection{Introduction}

Due to the increasing storage demand for natural gas and oil products a large number of storage facilities, based upon leached caverns in underground salt formations, have been constructed during recent years in North America and Europe. Cavern volumes of $300,000 \mathrm{~m}^{3}$ are not unusual in these plants. The underground storage concept has been preferred to surface tank farm storage for reasons of economy, safety and environmental protection.

In connection with the planning preparations for a future Danish gas transmission system Ris $\phi$ became involved in feasibility studies on a seasonal peakshaving storage facility in a salt dome by mid-1977, and the studies were terminated by end of 1978. The work was performed on a contractual basis for the stateowned company Dansk olie Naturgas $A / S$. Ris $\emptyset$ assumed the responsibility as a main consultant on the project and entered into close collaboration with the Danish Geological Survey and a series of sub-consultants at home and abroad to ensure access to supplementary know-how.

\subsection{Scope of Work}

The feasibility study included:

- Planning and evaluation of additional field investigations and associated laboratory tests with a view to verify site feasibility in principle.

- A conceptual design study on a complete storage facility.

- Rock-mechanical safety investigations of the cavern concept.

The former activities are reviewed brlefly and the latter in more detail in the following.

\subsection{Field Investigations and associated Laboratory Tests}

Based upon geological pre-feasibility studies the location of Ll. Torup in Northern Jutland was selected as the tentative site for a future peak-shaving storage facility (F1g.3.1). An exploratory well was drilled during April-May 1978 to a final depth of $1600 \mathrm{~m}$ in the salt dome, and oriented drill cores were extracted from different depths for subsequent laboratory testing of the rock salt chemical and mechanical properties. The results from these investigations indicated that the salt dome would be feasible for gas storage applications, but further investigations would be required to provide complete verification.

\subsection{Conceptual Design Study}

Development of the storage facility will include the establishment of a temporary leaching plant and a permanent gas storage and process 
Research on Energy Storage at Risø National Laboratory

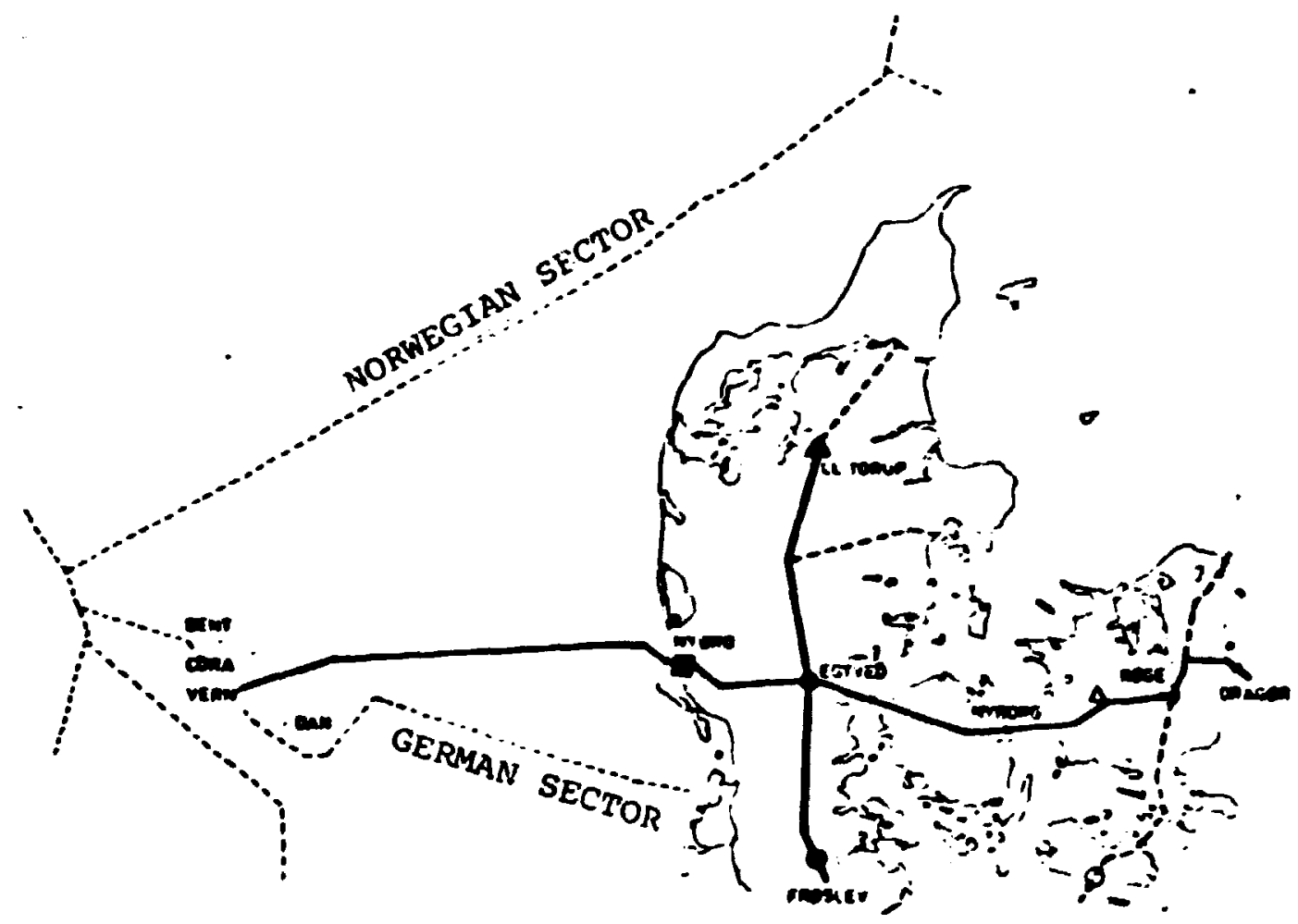

TRANSMISSION LINE

FUTURE TRANSMISSION LINE GAS TREATMENT PLAN'

STORAGE FACLLITY

POSSIBLE AQUIFER STORACE

COMPRESSOR STATION

FUTURE COMPRESSOR STATION

Fig. 3.1. Planned gas transmission 11 nes and storage site. 
Steen krenk et al.

plant. The latter will comprise a number of underground cavities, each of $350,000 \mathrm{~m}^{3}$ volume, and the associated surface plant equipment, such as: storage compressor plant, heating, drying and pressure reduction plant, and metering station. The surface plant will be of conventional design, independent of the location characteristica (Fig. 3.2.)

The conceptual study included technical and economic analysis of a wide range of potential storage development schemes, in which storage capacity and construction time were the main variables. Documentation from major European contractors was used as background information for the study.

\subsection{Rock-mechanical Safety}

As for normal engin ering structures, the designing of a safe cavern facility includes 2 main steps: detailed studies and overall weighing of the results. The main safety aspects related to gas storage caverns are leak-tightness, mechanical strength under extreme loadings ( $\max$. and $\mathrm{min}$. operating pressure occuring once a year), and long-term stability.

Caverns will typically be constructed at 1000-1500 m depths, where leak-tightness will be ensured by the high formation pressure (approx. 250 bar) and the plastic properties of the rock salt.

The plastic behaviour should also be taken into accolnt in the analysis of the safety margin against failure in the cavern walls. Two essentially different conditions should be fulfilled: first, the overlying salt strata should not be fractured at maximum operating pressure, and secondly, the cavern walls should remain stable at the lowest occur, ing gas pressure. The former condition is fulfilled by restricting the maxinum pressure to a level essentially below the total weight of the overlying strata, and by special design precautions for the casing assembly.

Design considerations related to lower gas pressures must include both the annual minimum operating gas pressure and also potential depressurization of the cavern to atmospheric pressure in case of accidents. It is therefore desirable to design the cavern for shortterm stability under atmospheric pressure.

Two types of stress analysis methods have been applied for the investigations of the low-pressura situation: an analytical approach based upon simplified assumptions concerning cavity geometry and material behaviour, and a non linear finite element approach using the AXISYM computer code (FIg. 3.3.). The results from the two methods showed good agreement in the critical area at cavern mid-height. Selected results from the finite element analysis are 11 lustrated in Fig. 3.4., which shows the extent of plastic areas round the maximum operating, minimum operating and atmospheric pressures, respertively.

Long-term cavern stability is related to a progressive volume reduction, which may have a gradually increasing impact upon overall operating economy, and may also lead to potential subsidence at surface level. Only the latter aspect is safety-related. 
Research on Energy Storage at Ris $\emptyset$ National Laboratory

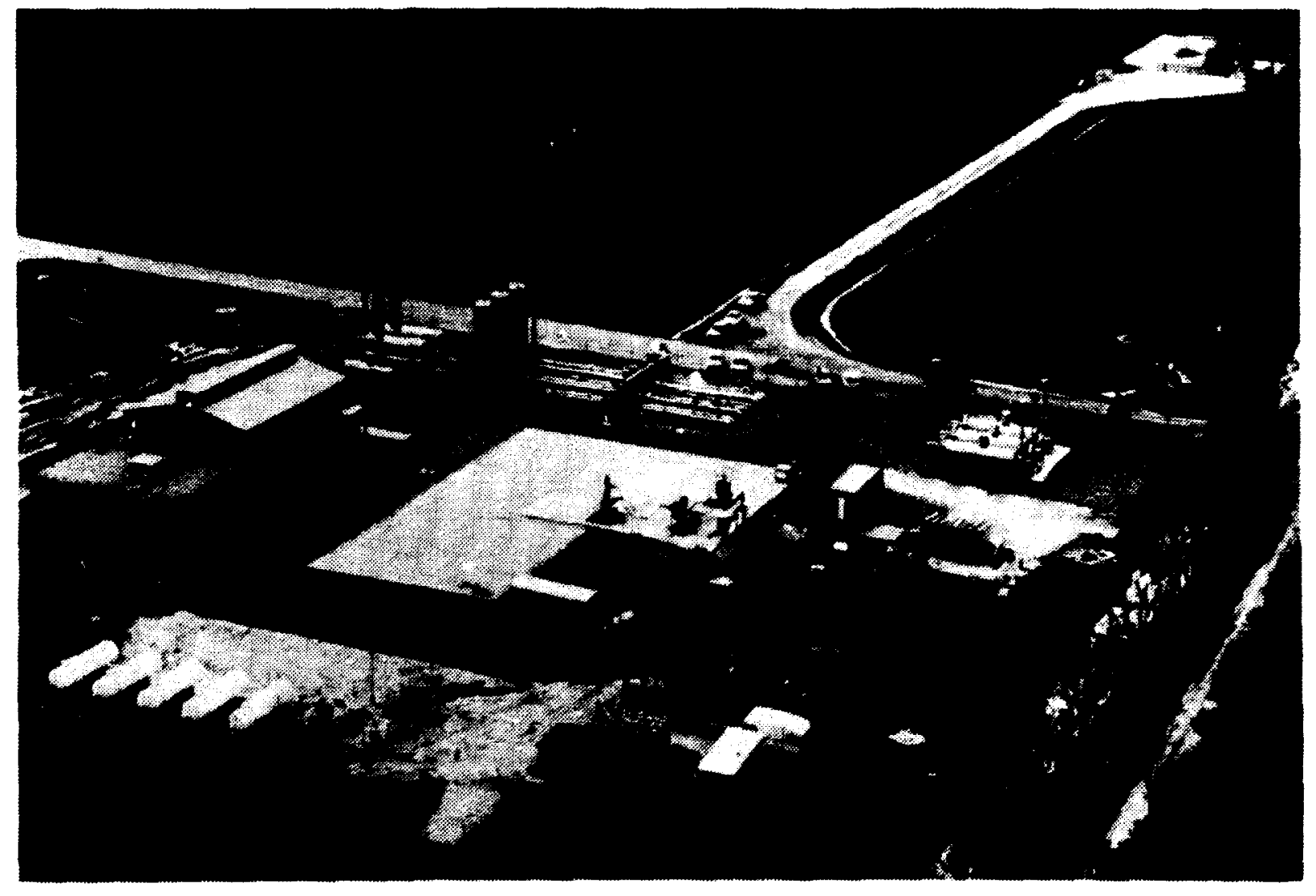

Fig. 3.2. Natural gas storage plant with underground stcrage in Northwest Germany. 
Steen Krenk et al.

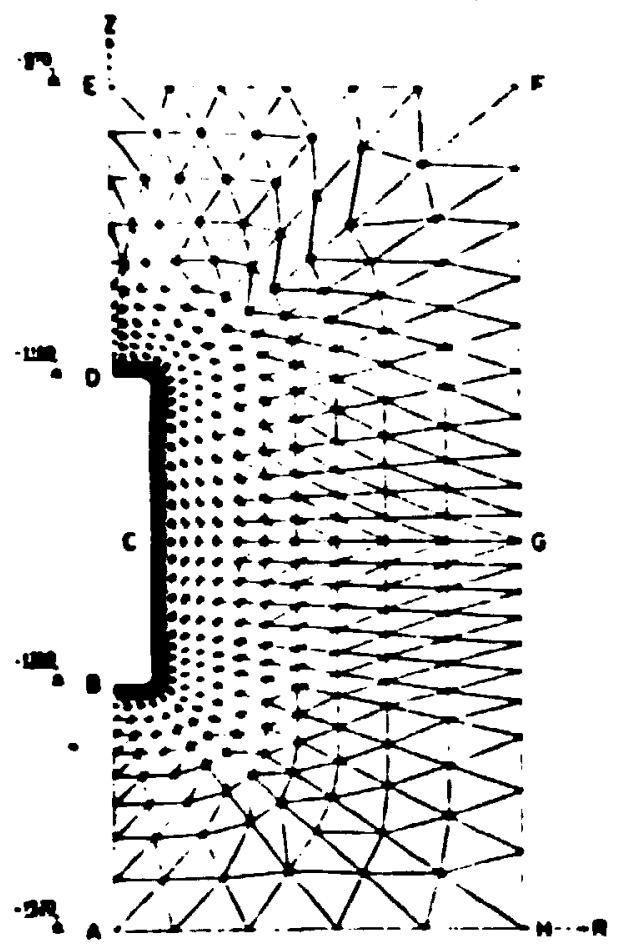

Fig. 3.3. AXISYM-mesh of idealized cavern geometry.

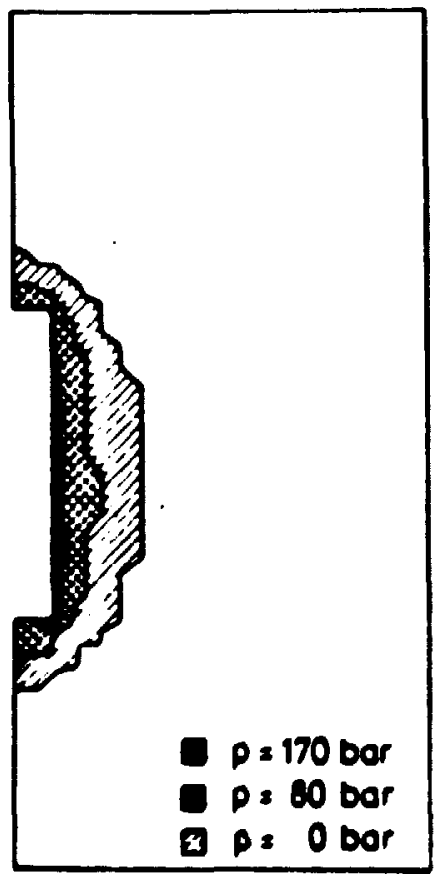

F1g. 3.4. Areas of nonlinear material behaviour around cavern. 
Research on Energy Storage at Risø National Laboratory

3.6. Future Activities

At present Ris $\emptyset$ is involved in subsequent stages of the storage project, including both general engineering activities and also more detailed'studies on rock-mechanical safety.

\subsection{References}

S. Krenk, Internally Pressurized Spherical and Cylindrical

Cacities in Rock Salt, Int. J. Rock Mech. Min. Sci. \&

Geomech. Abstr. 15, 219-224 (1978).

Niels Saabye Ottosen, A Constitutive Model for Rock Salt, Ris $\varnothing$ Report No. 383 (August 1978).

N.S. Ottosen S. Krenk, Nonlinear Analysis of Cavities in Rock Salt, Int. J. Rock Mech. Mech. Min. Sci. Geomech. Abstr. 16, 245-252 (1979).

\section{ENERGY STORAGE BASED UPON METAL-HYDROGEN SYSTEMS}

Bjørn Vigeholm

\subsection{General}

It is well-known that certain metals and inter-metallic compounds react with hydrogen to form metal hydrides. These reactions are exothermic and may be reversed by addition of heat:

Metal + Hydrogen $\longrightarrow$ Metalhydride + heat.

Three systems are at present under serious considerations for energy storage purposes:

FeT1 and alloys $\left(\mathrm{Fe}_{1-\mathrm{x}} \mathrm{TiMe}_{\mathrm{x}} ; \mathrm{Me}: \mathrm{Mn}, \mathrm{Ni}, \mathrm{Cu}\right)$

$\mathrm{AB}_{5}$ intermetallic compounds (A: Rare earth metals or substitutes

' B: Group VIII, e.g. LaNi $_{5}$,

$$
\left.\mathrm{CaCo}_{5}\right)
$$

Mg and alloys, e.g. MgNi $; \mathrm{MgCu}_{x}$.

of the three systems Mg is far the least investigated, and in general considered to have the least probability of becoming a practicable bydrogen carrier.

Very roughly outlined, the differences between the three systems are:

$$
\begin{aligned}
\text { FeTiH } & =- \\
& -28 \text { by weight hydrogen, } \\
& \text { Low working temperature for the applicable } \\
& \text { dissociation pressure range } 1-20 \text { bar, } \\
& \text { - Reasonably high reaction rate, } \\
& \text { - Low heat of formation, } \\
& \text { - Relatively expensive, resources limited, }
\end{aligned}
$$




\section{Bjørn Vigeholm}

LaNi $_{5} \mathrm{H}_{7}:-1.58$ by weight hydrogen,

- Reasonably low working temperature

- High reaction rate.

- High heat of formation,

- Expensive, resources 1 imited.

$\mathrm{MgH}_{2}: \quad-7.68$ by weight hydrogen,

- High working temperature, > $250^{\circ} \mathrm{C}$,

- Reaction rate, not well known,

- High heat of formation.

- Inexpensive, abundant.

At Risø National Laboratory we have chosen to investigate the $\mathrm{Mg}^{\mathrm{MgH}} \mathbf{2}$ system from the following considerations:

1) If a medium for energy storage shall have any impact it must be based upon a low cost material which can be supplied universally. The hydrogen concentration by weight in $\mathrm{MgH}_{2}$ is 4-5 times that of $\mathrm{FeT}_{\mathrm{H}}$, and $\mathrm{LaNi}_{5} \mathrm{H}_{7}$. Furthermore magnesium is by far the cheapest material; so with the actual marked prices, hydrogen storage per unit price is approximately 12 times as great in Mg as in FeTi and compared to the LaNi 5 group even 40-100 times as great.

2) The high enthalpy figure, $-75 \mathrm{~kJ} / \mathrm{mol} \mathrm{H}$ (upper heat of combustion, $285 \mathrm{~kJ} / \mathrm{mol} \mathrm{H}_{2}$ ) is not necessarily a disadvantage, as it permits heat storage applications.

3) For storing low grade waste heat the working temperature of $\mathrm{Mg}-\mathrm{MgH}_{2}$ is too high, but a hybrid system with one of the other hydride systems as a pick-up and Mg as main storage is quite conceivable.

\subsection{Results}

$\mathrm{Mgh}_{2}$ was not synthesized from its element until 1951 and only under extfeme conditions: 400 bar, $700^{\circ} \mathrm{C}$. Probably because of the early reported difficulties, relatively little literature is available.

Most researches claim:

- slow hydriding and dehydriding rates,

- Difficulties in activating the metal,

- Hydrogen concentrations substantially below the stolchiometric composition.

- High susceptibility to poisoning from many contaminants, e.g. $0, s$, hydrocarbons.

- Reduced uptake after even a small number of sorption cycles.

Upon this background it 1 s somewhat surprising that our results are contradictory on almost all points, cf. Fig. 4.1.:

We find the reaction rates to be comparable to those found in FeTi. No need for special activation measures, no deviation from stoichiometric compositions.

No adverse effect of exposure to a1r, 1.e. no apparent poisoning 
Research on Energy Storage at Ris $\emptyset$ National Laboratory

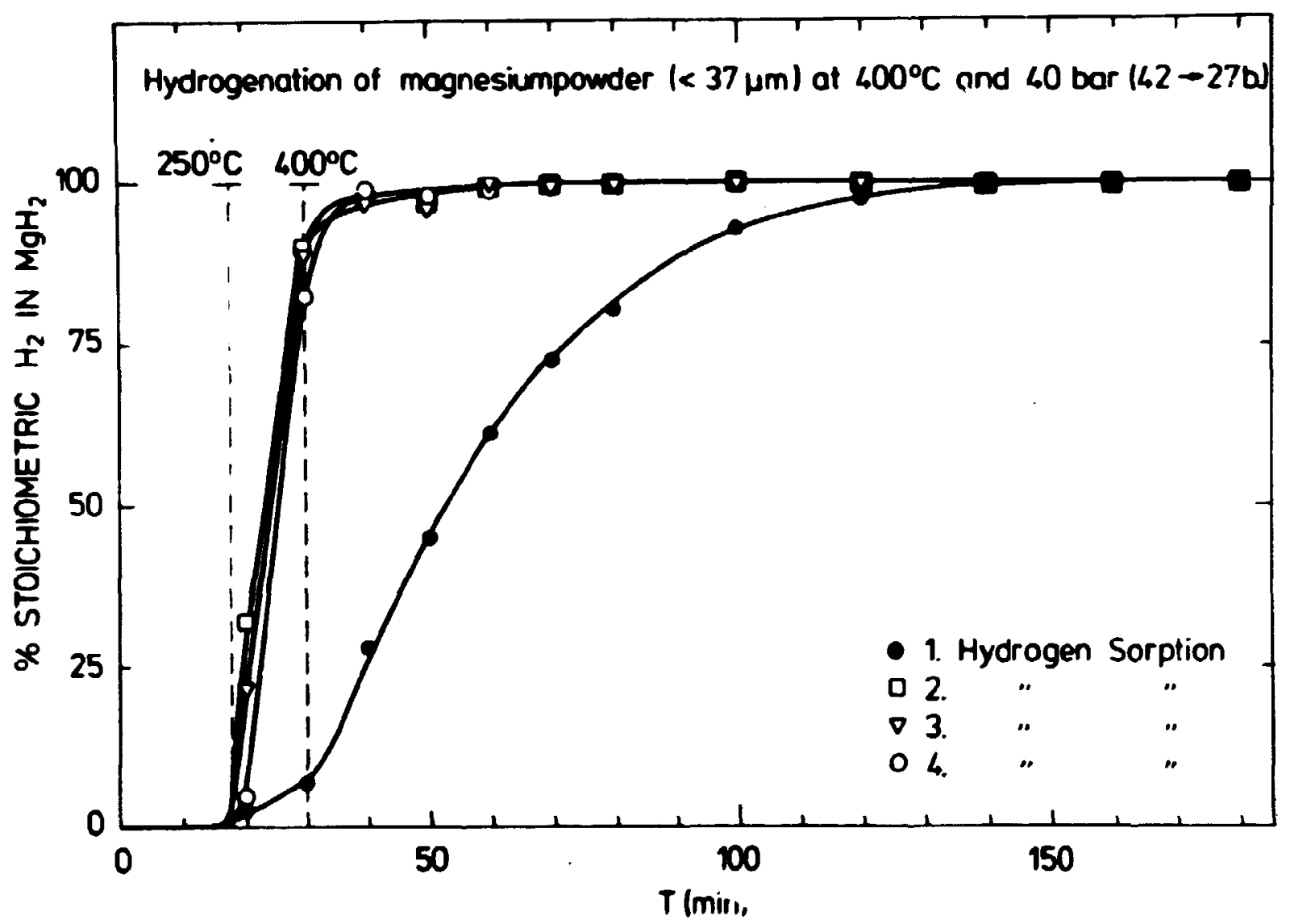

Fig. 4.1. Hydrogen sorption in $\mathrm{Mg}$ at $400^{\circ} \mathrm{C}, 400$ bar 1 to 4 denotes a sequence of hydrogenations of the same sample.

The nominal $400^{\circ} \mathrm{C}$ reached in approximately $35 \mathrm{~min}$. Starting temperature $22-24^{\circ} \mathrm{C}$. 
Bjørn Vigeholm

by oxygen.

Increased reaction rate with cycling.

It should be pointed out that our experiments have so far been very crude. They have been carried out in preliminary experimental setups, which do not permit precise statements concernina time measurements as slow heating and cooling was involved.

That the above statements are qualitatively correct has been checked in several ways. Different Mg powders from different suppliers were used, the absorbed anount of hydrogen was measured by pressure changes in a known volume as well as gravimetrically. chemical analyses were done on the material before and after hydrogen sorption, etc.

\subsection{Programe}

The present programe contains

- Evaluation of kinetic data for the sorption cycle (in newly designed facilities)

- Investigation of mechanically relevant properties, e.g. packing behaviour.

- Construction of a laboratory scale hydrogen storage unit.

- Systematic investigation of the effect of possible contaminants in practical application.

- Investigation of the potentials of a heat storage system. Preliminary calculations indicate that Mg might be competitive with water tanks, even disregarding the lack of heat loss during storage of the hydride system.

\subsection{Impact on Energy Supply}

Although the possible impact of the $\mathrm{Mg}-\mathrm{H}$ system is closely related to the general fate of the predicted hydrogen economy we feel that the system has a number of potentials, e.g. in waste heat recovery.

With the 12 times lower price (compared to FeTi) and the high safety in handling (compared to gaseous or liguid hydrogen), magnesium hydride is quite attractive as a means of making hydrogen available for many uses. 
Research on Energy Storage at Risø National Laboratory

Tuble 4.1

Hydrogen and Energy Density of Different

Hydrogen Storages

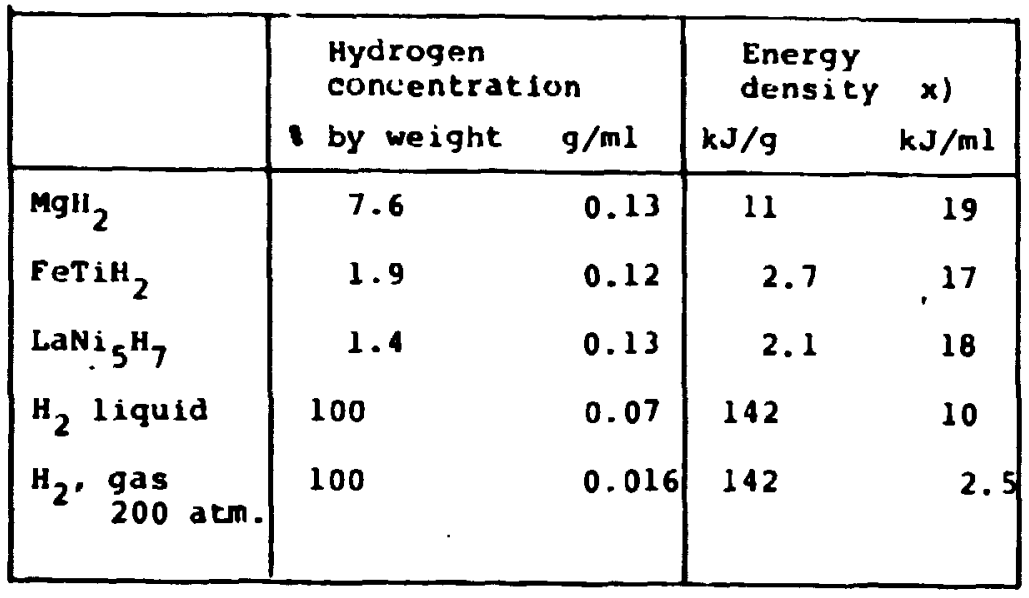

x) upper heat of combustion.

Table 4.2

Energy Density Comparison

Automotive Power Sources

\begin{tabular}{|c|c|c|c|c|c|}
\hline Power Source & $\begin{array}{l}\text { Energy } \\
\text { Density } \\
\text { whr/kg }\end{array}$ & $\mathrm{MJ} / \mathbf{k g}$ & $\begin{array}{l}\text { Conversion } \\
\text { Efticiency }\end{array}$ & $\begin{array}{l}\text { Net } \\
\text { whr / kg }\end{array}$ & $\mathbf{M J} / \mathbf{k g}$ \\
\hline $\begin{array}{c}\text { Pb/acid battery } \\
\text { Present } \\
\text { Advanced }\end{array}$ & $\begin{array}{l}30 \\
50\end{array}$ & $\begin{array}{l}0.11 \\
0.18\end{array}$ & $\begin{array}{l}70 \\
70\end{array}$ & $\begin{array}{l}21.0 \\
35.0\end{array}$ & $\begin{array}{l}0.08 \\
0.13\end{array}$ \\
\hline Li/MS Battery & 150 & 0.5 & 70 & 105 & 0.40 \\
\hline FeTiH 1.7 a,b & $516^{c}$ & 1.9 & 30 & 154 & 0.55 \\
\hline $\mathrm{Mg}_{2} \mathrm{NiH}_{4} \quad \mathrm{a}, \mathrm{b}$ & $1121^{c}$ & 4,0 & 30 & 336 & 1.2 \\
\hline $\mathrm{MgH}_{2}(1 \mathrm{OSN \textrm {NL }})^{\mathrm{a}, \mathrm{b}}$ & $2555^{c}$ & 9,2 & 30 & 767 & 2.8 \\
\hline Gasoline & $12880^{c}$ & 46 & 23 & 2962 & 10.7 \\
\hline
\end{tabular}

a No allowance for container weight

b Based on avallable hydrogen

L.e. FeTiH $1.7 \rightarrow$ FeTiH $_{0.1}$

$\mathrm{Mg}_{2} \mathrm{NiH} \rightarrow \mathrm{Mg}_{2} \mathrm{NLH}_{0.3}$

$\mathrm{MgH}_{2} \rightarrow \mathrm{MgII}_{0 . \mathrm{NS}}$

c Based on lower heat of combustion 
Knud Ladekarl Thomsen

\title{
5. STRATIFIED STORAGE FOR SOLAR HEATING SYSTEMS
}

\author{
Knud Ladekarl Thomsen
}

In a water heat storage tank for solar heating systems the conditions are usually so quiet that some temperature stratification will occur spontaneously. This tendency is regarded as an advantage because any mixing in the tank of hot and cold water will cause a loss in collector efficiency. This is due to increased collector losses if the relatively cold bottom water determining the collector inlet temperature is mixed with hot water from a higher level in the tank.

Some investigations regarding optimal utilization of temperature stratification have been made. Obviously, measures should be taken to ensure that water heated in the solar collector is returned to the storage tank at the level where the water temperature corresponds to the collector outlet temperature. Similarly the outlet from the storage to hot water and space heating should not be taken from an unnecessarily high temperature level; when returned to the tank after being cooled, the appropriate input level is that where the temperature fits. If a heat exchanger is inserted between the collector and the tank, a separate exchanger is oreferable from the stratification point of view, because a simple imunersion type exchanger inevitably causes convective mixing in the tank.

All these efforts to maintain optimal stratification may not seem worthwhile in the usual mode of collector operation, where the flow rate is high. However, fully stratified operation of the storage facility allows one to reduce the collector flow rate without any penalty on the system efficiency. This can be shown theoretically on the basis of the Hottel-Bliss-Whillier equation. Thus stratification gives a degree of freedom which may result in a better utilization of the unpredictable sunlight.

For Instance, starting with a cold storage in the morning, useful temperatures can quickly be attained in the top of the tank, if the collector flow is low, producing a high temperature increase in the collector. As another example, after a sunny day, the late afternoon sunshine can be utilized with better efficlency here than in connection with mixed storage, because the lower portion of the tank may still be relatively cool.

As seen from the consideration above there may be some advantages in a stratified operation, but the phenomena are interrelated in a complicated manner, which necessitates computer calculations which deal with different operating strategies. We are investigating the phenomena and hope to reach a conclusion concerning these matters in the not too distant future. 
Rise National Laboratory

Title and author(s)

Date

RESEARCH ON ENERGY STORAGE AT

Department or group

RIS $\emptyset$ NATIONAL LABORATORY

Reactor Technology

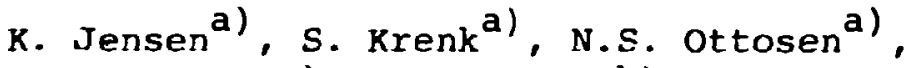

I. Rasmussen ${ }^{\text {) }}$, O. Rathmann ${ }^{\text {b) }}$, J. Reffstrup ${ }^{\text {) }}$,

K.L. Thomsen ${ }^{b)}$, B. Vigeholm ${ }^{c)}$, and J. Würtz ${ }^{b)}$

Group's own registration number (s)

Copies to

This paper was presented at the International Assembly on Energy Storage held from May 27

Authors (100) to June 1, 1979 in Dubrovnik, Yugoslavia.

Library (100)

It contains a review of some of the research projects on energy storage at Ris $\varnothing$ National Laboratory. Some of the already obtained results are presented together with planned activities for the next few years.

Some of the projects are carried out in close cooperation with the Laboratory for Energetics at the Technical University of Denmark and the Geological Survey of Denmark.
a) Engineering Department
b) Department of Reactor Technology
c) Metallurgy Department
d) Laboratory of Energetics, Technical University of Denmark, DK 2800 Lyngby, Denmark.

Avallajle on request from Riso Library, Risq National Laboratory (Risф Bibliotek), Forsqganlag R1gף), DK-4000 Roskilde, Denmark

Telephore: (03) 3712 12, ext. 2262. Telex: 43116 